\title{
Recent perspectives on the medicinal potential of ginger
}

\author{
This article was published in the following Dove Press journal: \\ Botanics: Targets and Therapy \\ 20 October 2015 \\ Number of times this article has been viewed
}

\author{
KDPP Gunathilake \\ HP Vasantha Rupasinghe ${ }^{2}$ \\ 'Department of Food Science and \\ Technology, Faculty of Livestock, \\ Fisheries and Nutrition, Wayamba \\ University of Sri Lanka, Makandura, \\ Gonawila, Sri Lanka; ${ }^{2}$ Department of \\ Environmental Sciences, Faculty of \\ Agriculture, Dalhousie University, \\ Truro, NS, Canada
}

\begin{abstract}
Ginger (Zingiber officinale) is a globally known food and flavoring ingredient which is also reputed for its wide range of medicinal properties. The rhizome of ginger consists of a unique homologous series of compounds, gingerols, which are the major phenolic plant secondary metabolites responsible for its unique flavor and health benefits. Over the last 2 decades, extensive research has been conducted to identify bioactive constituents and medicinal potential of ginger. This review deliberates chemical composition as well as the most recent research findings on potential health benefits of ginger, including its antimicrobial, anti-inflammatory, blood pressure-lowering, cholesterol-lowering, antiplatelet aggregation, chemopreventive, antioxidant, and hypoglycemic properties.
\end{abstract}

Keywords: ginger, gingerols, medicinal properties, Zingiber officinale, health

\section{Introduction}

Ginger (Zingiber officinale Roscoe) is a well-known and widely used spice and condiment, especially in Asia. The rhizome of ginger contains several interesting bioactive constituents and possesses health-promoting properties. Interestingly, in recent years, the demand for ginger has been growing in North America, not only for the use as a food ingredient, but also for its health benefits. ${ }^{1}$ Ginger has been widely used in Chinese, Ayurvedic, and Unani-Tibb medicines. ${ }^{2}$ Based on the scientific findings through in vitro, in vivo, and human clinical trials, ginger has the potential to treat many aspects of cardiovascular diseases such as hyperlipidemia, ${ }^{3}$ platelet aggregation, ${ }^{4}$ and hypertension. ${ }^{5}$ The antiatherogenic effect of ginger is associated with reductions in plasma and hepatic low-density lipoprotein cholesterol (LDL-C) levels, as well as their susceptibility to oxidation and aggregation. ${ }^{3,6}$ The pungency of fresh ginger is primarily due to the gingerols which are a homologous series of phenolic compounds, whereas the pungency of dried ginger is mainly due to the presence of shogaols, mainly (6)-shogaol, which are dehydrated forms of gingerols. ${ }^{2}$ In the cardiovascular system, both (6)-shogaol and (6)-gingerol are the two active components of ginger which produce a depressor response on blood pressure at lower doses. ${ }^{7}$ Because of these health-promoting properties, ginger can be considered as an active ingredient for designing functional foods targeted for reducing the risk of cardiovascular disease. ${ }^{8,9}$ This review discusses the potential health benefits of ginger with special reference to phytochemical composition and physiological benefits such as anticancer, anti-inflammatory, antioxidant, and cardioprotective properties.
Rupasinghe

Department of Environmental Sciences, Faculty of Agriculture, Dalhousie University, Truro, NS B2N 5E3, Canada Tel +l 9028936623

Fax + I 902893 I404

Email vrupasinghe@dal.ca 


\section{Phytochemical composition}

The main pungent compounds in fresh ginger are gingerols, whereas the pungency of dry ginger is mainly due to shogaols, for example [6]-shogaol, which are dehydrated forms of [6]-gingerols. Most abundant gingerol found in ginger is [6]-gingerol. ${ }^{10}$ Other gingerols with different chain lengths are also present in comparatively small quantities. ${ }^{2}$ Jolad et $\mathrm{al}^{11}$ reported that they have identified 51 compounds on organically grown fresh ginger, 31 compounds were previously reported as constituents of ginger and additional 20 are yet to be characterized. The identified compounds included gingerols, shogaols, paradols, dihydroparadols, [3]-dihydroshogaols, acetyl derivatives of gingerols, gingerdiols, mono- and di-acetyl derivatives of gingerdiols, 1-dehydrogingerdiones, diarylheptanoids, zingiberene, phellandrene and methyl ether derivatives of some of these compounds. In addition to [6]-gingerol, [4]-, [7]-, [8]-, and [10]-gingerol were identified. Figure 1 shows the chemical structures of the major gingerols and shogaol present in ginger. Masuda et al ${ }^{12}$ suggested that the substituents on the alkyl chain of gingerol and related compounds might contribute to antioxidant properties. Over 50 components in ginger oil have been characterized and these are mainly monoterpenoids and sesquiterpenoids. ${ }^{2}$

\section{Antibiotic/antimicrobial properties}

Ginger and its products have been used widely as a food spice as well as in herbal medicine. In particular, gingerolrelated components have been reported to possess antimicrobial and antifungal properties, as well as several

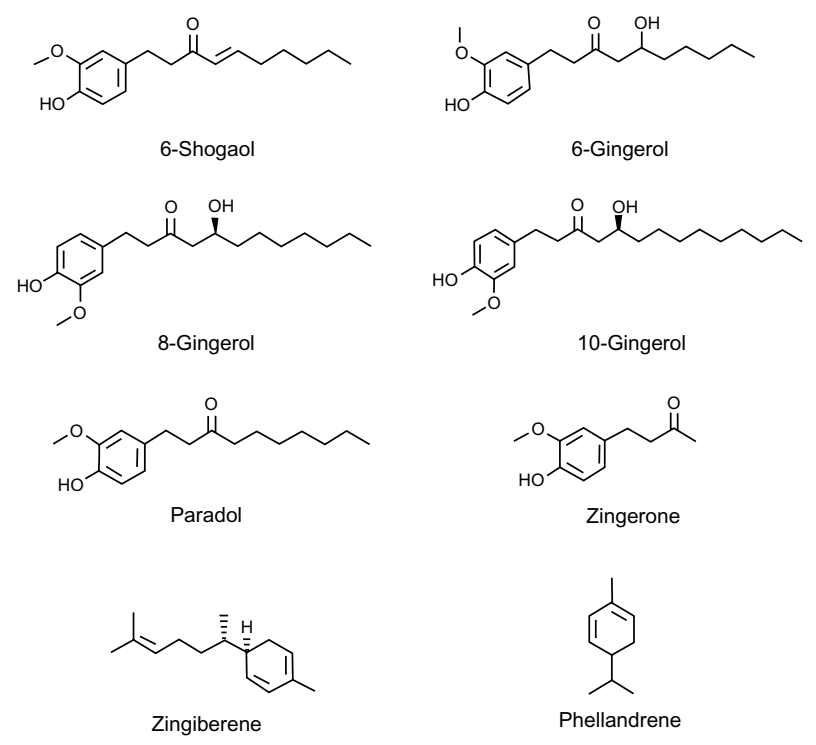

Figure I Chemical structures of selected major bioactive constituents of ginger. anti-infective properties. ${ }^{13}$ Most of the reported findings are through in vitro studies, however, a few preclinical investigations are published. The antibacterial activity of different solvent extracts of ginger was studied by Malu et al, ${ }^{14}$ and it was found that $n$-hexane, ethyl acetate, and ethanol extracts of ginger showed a bacterial growth inhibition activity in a dosedependent manner. Ekwenye and Elegalam ${ }^{13}$ have reported an inhibitory effect of ethanol extract of ginger on Escherichia coli and Salmonella typhimurium with a minimum inhibitory concentration (MIC) between 75 and $250 \mathrm{mg} / \mathrm{mL}$.

Ethanol and $n$-hexane extracts of ginger exhibit antibacterial activities against three anaerobic gram-negative periodontal disease-causing bacteria such as Porphyromonas gingivalis ATCC 53978, Porphyromonas endodontalis ATCC 35406, and Prevotella intermedia ATCC 25611. Two highly alkylated gingerols, [10]-gingerol and [12]gingerol, seem to be effective in inhibiting the growth of these oral pathogens at a MIC range of $6-30 \mu \mathrm{g} / \mathrm{mL}$ and killing these oral pathogens at a minimum bactericidal concentration range of $4-20 \mu \mathrm{g} / \mathrm{mL} .{ }^{15}$ Four ginger components namely, [6]-dehydrogingerdione, [10]-gingerol, [6]-shogaol, and [6]-gingerol have shown antibacterial effects against extensively drug-resistant Acinetobacter baumannii. ${ }^{16}$

Ethanol extracts of ginger on Staphylococcus aureus and Streptococcus pyogenes have shown the similar effect like that of conventional antibiotics such as chloramphenicol, ampicillin, and tetracycline, ${ }^{17}$ and the MIC of the extracts ranged from $0.3 \mathrm{ng} / \mathrm{mL}$ to $0.7 \mu \mathrm{g} / \mathrm{mL} .{ }^{18}$ Limited synergism capacity between 13 antimicrobial drugs and 8 plant extracts, including ginger, against $S$. aureus strains was verified by Betoni et al ${ }^{19}$ Further, ginger root has been used traditionally for the treatment of gastrointestinal ailments such as motion sickness, dyspepsia, and peptic ulcer disease. Helicobacter pylori is the primary etiological agent associated with these diseases, and the methanol extract of the dried powdered ginger rhizome, fractions of the extract, and the isolated constituents, 6-, 8-, 10-gingerol and 6-shogaol showed inhibitory effect on 19 strains of $H$. pylori with a MIC range of $6.25-50 \mu \mathrm{g} / \mathrm{mL} .{ }^{20}$

\section{Antioxidant properties}

Ginger has been used as a spice for over thousands of years and its rhizomes and extracts contain phenolic compounds such as 6-gingerol and its derivatives, which have a high antioxidant activity. ${ }^{21-23}$ It has also been revealed by many authors that the ginger has antioxidant properties. The substituent on the alkyl chain of these compounds might 
contribute to both radical scavenging effect and inhibitory effects against the peroxyl radical-induced peroxidation of liposome. The antioxidant activity might be due to radical scavenging activity. ${ }^{12}$ It has been shown that [6]-gingerol possesses strong antioxidant activity both in vivo and in vitro. ${ }^{24}$ Similarly, Gunathilake and Rupasinghe ${ }^{25}$ have reported that pure phenolic bioactives of ginger, such as [6]-gingerol, were strong inhibitors of copper-induced low LDL-C oxidation in vitro. Ginger has been shown to be effective in prevention of ultraviolet $\mathrm{B}$ (UVB)-induced reactive oxygen species production and cyclooxygenase-2 (COX-2) expression, and a possible therapeutic agent against UVB-induced skin disorders. ${ }^{24}$ In another study, it was reported that ginger causes a decrease in lipid peroxidation, an increase of plasma antioxidant capacity, and a reduction in renal nephropathy in rats. ${ }^{26}$ Aeschbach et $\mathrm{al}^{27}$ found that gingerol is a good scavenger of peroxyl radicals generated by pulse radiolysis suggesting that [6]-gingerol could be used as a "natural" replacement for "synthetic" antioxidant food additives. Gunathilake et $\mathrm{al}^{9}$ reported that a functional beverage consists of [6]-gingerol-rich extract that exhibits hypocholesterolemic effect in spontaneously hypertensive rats. Furthermore, water extracts of ginger can be incorporated into fruit-based functional beverages designed for cardioprotection. Oxidation of LDL-C has been suggested to play a significant role in the process of development of atherosclerosis. ${ }^{28}$ It has been suggested that among all in vitro antioxidant capacity assays, measuring LDL-C antioxidant activity is more pathophysiologically important and more informative for screening antioxidant activity of foods for preventing atherosclerosis. ${ }^{29}$ Copper-induced LDL-C oxidation inhibition by water, ethanol, methanol, ethyl acetate, and hexane extracts of ginger were $43 \%, 71 \%, 76 \%, 67 \%$, and $67 \%$, respectively, at their optimum extraction conditions..$^{25,30}$ In a rat study, ginger at $1 \%(\mathrm{w} / \mathrm{w})$ lowers the lipid peroxidation by maintaining the activities of the antioxidant enzymes such as superoxide dismutase (SOD), catalase, and glutathione peroxidase and indicated that the ginger is comparatively as effective as ascorbic acid as an antioxidant. ${ }^{31}$ The 2,2-diphenyl-1-picril hydrazyl radical scavenging activity of ginger is comparable to that of butylated hydroxytoluene and it was shown that the ginger extract chelates $\mathrm{Fe}^{3+}$ in the solution. ${ }^{32}$ Leaves of ginger have also shown higher antioxidant activity and phenolic contents compared with the rhizomes and stems of ginger. ${ }^{33}$ However, it has been shown that ferric-reducing antioxidant power activity of the rhizomes is higher than that of leaves. ${ }^{33}$ Gunathilake and Rupasinghe ${ }^{30}$ have also reported an ultrasonication-based extraction method to prepare [6]-gingerol-rich water-based ginger extract for functional food formulations.

\section{Hypoglycemic properties}

Diabetes mellitus is one of the major metabolic disorders, and it is a global epidemic. Many traditional plant treatments exist as a hidden wealth of potentially useful natural products for diabetes treatment and management. ${ }^{34}$ Ginger has been traditionally used in the treatment of diabetes mellitus, and studies have reported the hypoglycemic properties of ginger in in vitro and in vivo. Oral administration of aqueous ginger extract to streptozotocin (STZ)-induced diabetic rats for a period of 30 days showed a dose-dependent antihyperglycemic effect, and the plasma glucose level decreased by $68 \%$ at the dose of $500 \mathrm{mg} / \mathrm{kg}$ body weight daily, indicating that ginger is a potential phytomedicine for the treatment of diabetes. ${ }^{35}$ Similarly, other studies have also confirmed that both ginger extracts ${ }^{36}$ as well as 6-gingerol ${ }^{37}$ have shown hypoglycemic effect on diabetic rats. Aqueous extracts of ginger rhizomes have been studied to evaluate their antidiabetic effects on protein glycation and on the diffusion of glucose in vitro in a dose-dependent manner. This antidiabetic potential of ginger is mainly through the inhibition of the glucose diffusion and, to a limited extent, by reducing the glycation of proteins. ${ }^{38}$ In a study assessing the effect of several plant foods on glucose uptake activity in L6 myotubes, it has been reported that onion and ginger are potent regulators of glucose transport. ${ }^{39}$

The modulatory effects of spices (including ginger) on the metabolic syndrome and oxidative stress in STZnicotinamide diabetic rats have shown that ginger alleviates (80\%-97\%) the signs of the metabolic syndrome (hyperglycemia and dyslipidemia) by increasing the production of insulin $(26 \%-37 \%)$, enhancing the antioxidant defense system (31\%-52\%), especially glutathione, and decreasing lipid peroxidation (60\%-97\%). ${ }^{40}$ Advanced glycation end products (AGE) are associated in the development of several pathophysiological conditions, including diabetic cataract, and ginger is a prominent agent to inhibit the AGE formation in vitro as well as in vivo. ${ }^{41}$ Ginger has a potential to prevent diabetic cataract in rats mainly through its antiglycation potential and to a lesser extent by inhibition of the polyol pathway, indicating that the ginger may be explored for the prevention or delay of diabetic complications. ${ }^{41}$

Ethyl acetate extract of ginger at $5 \mu \mathrm{g} / \mathrm{mL}$ concentration has been shown to enhance glucose uptake in cell lines. Further, in an antibody-based study in treated cells the effect of ethyl acetate extract of ginger in expressing GLUT4 on 
the cell surface membrane was revealed. These findings experimentally proved that the antidiabetic effect of ginger is initiated by its antioxidant and antiglycation properties and the potential to express or transport GLUT4 receptors from internal vesicles. ${ }^{42}$ In a study evaluating the effects of ginger on some biochemical parameters in type 2 diabetic patients in a randomized double-blind placebo-controlled trial, it was found that the ginger supplementation significantly lowered the levels of glucose and increased the quantitative insulin-sensitivity check index. Thus, ginger supplementation improved the insulin sensitivity and some fractions of lipid profile in type 2 diabetic patients. ${ }^{43}$ In another human clinical trial with diabetic and hypercholesterolemia subjects, it was reported that a dose of $3 \mathrm{~g} / \mathrm{d}$ for a period of 30 days resulted in a significant reduction in blood glucose, total cholesterol, triglycerides, LDL-C, and very low-density lipoproteincholesterol (VLDL-C) levels. ${ }^{44}$

Gingerols, the major pungent components of ginger, are known to improve diabetes, including the effect of enhancement against insulin sensitivity. Extracts of ginger prepared using hexane, ethyl acetate, methanol, 70\% methanol-water, and water were studied to determine the potential of these extracts to inhibit key enzymes relevant to type 2 diabetes, and the results indicated that ginger has a very good potential for inhibition of $\alpha$-glucosidase and $\alpha$-amylase activities, which is important for the management of type 2 diabetes. $^{45}$

\section{Anti-inflammatory properties}

Since ancient times, in various populations worldwide, inflammatory disorders and related diseases like rheumatic conditions have been treated with ginger or ginger-derived formulations because of its broad anti-inflammatory actions. ${ }^{46}$ Recent research findings provide scientific support for the long-held belief that ginger contains phytochemicals with anti-inflammatory properties. Some phytochemical constituents of ginger share pharmacological properties of nonsteroidal anti-inflammatory drugs (NSAIDs). ${ }^{47}$ In vitro studies and several animal trials provide evidence that ginger has the capacity to ameliorate symptoms of inflammationassociated conditions such as arthritis. ${ }^{48}$ Based on an animal study, ethanol extract of ginger possesses analgesic and antiinflammatory properties, and thus this gives pharmacological support to folkloric, ethnomedical uses of ginger in the treatment and management of painful, arthritic inflammatory conditions. ${ }^{49}$ Hexane, ethyl acetate, and methanol extracts of ginger have the potential to inhibit key enzymes associated with inflammation such as cyclooxygenase (COX) ${ }^{45}$
Ginger also suppresses prostaglandin synthesis through inhibition of COX-1 and COX-2 and leukotriene biosynthesis by inhibiting 5-lipoxygenase. It is interesting to note that ginger has no or fewer side effects when compared with NSAIDs. ${ }^{47}$ Ginger extract also inhibits the induction of several genes involved in encoding the inflammatory response proteins such as cytokines and chemokines, indicating that ginger modulates biochemical pathways which are activated due to chronic inflammation. ${ }^{47}$

Gingerols inhibit the production of inflammatory mediators such as nitric oxide and Prostaglandin E2 (PGE 2$)$ in a dose-dependent manner. ${ }^{50}$ The expressions of nuclear factor $\kappa-\mathrm{B}$ and the proinflammatory tumor necrosis factor alpha is reduced in rats with liver cancer when given a diet supplemented with ginger, indicating that ginger may act as an anticancer and anti-inflammatory agent. ${ }^{51}$ Acetone extract of ginger exerted a dose-dependent topical anti-inflammatory activity in mice irrespective of the gingerol concentration in the extract. ${ }^{52}$ Ginger at the dose of $200 \mathrm{mg} / \mathrm{kg}$ body weight per day significantly suppressed the incidence and severity of adjuvant-induced arthritis in rats by modulating the production of anti-inflammatory/proinflammatory cytokines and activating the antioxidant defense system. These effects are comparable with indomethacin, an NSAID. ${ }^{53}$ Inhibition of acetic-acid-induced writhing response and formalin-induced licking time in the late phase was shown with intraperitoneal administration of [6]-gingerol in the range of $25-50 \mathrm{mg} / \mathrm{kg}$. Further, [6]-gingerol at a range of $50-100 \mathrm{mg} / \mathrm{kg}$ has also produced an inhibition of paw edema induced by carrageenin, suggesting that [6]-gingerol possesses analgesic and antiinflammatory activities. ${ }^{54}$

\section{Cholesterol-lowering properties}

In a study of experimental rats, a low dose of ginger $(50 \mathrm{mg} / \mathrm{kg} / \mathrm{d})$ showed no effect on reduction in the serum thromboxane- $\mathrm{B}_{2}$ levels and cholesterol levels although oral administration caused significant changes in the serum $\mathrm{PGE}_{2}$. However, high doses of ginger $(500 \mathrm{mg} / \mathrm{kg} / \mathrm{d})$ lower the serum $\mathrm{PGE}_{2}$ and cholesterol level. ${ }^{55}$ The results suggest that ginger could be used as a cholesterol-lowering agent. Oxidative modification of LDL-C is thought to play a key role in the pathogenesis of atherosclerosis. An ex vivo study on the effect of standardized ginger extract on the development of atherosclerosis in apolipoprotein E-deficient $\left(\mathrm{E}^{0}\right)$ mice showed a $44 \%$ reduction in aortic atherosclerotic lesion areas, $27 \%$ reduction in plasma triglycerides, and $29 \%$ reduction in cholesterol, as well as a reduction of VLDL-C and LDL-C by 58\% and 33\%, respectively, in mice fed with 
$250 \mu \mathrm{g}$ of ginger extract/day. Furthermore, consumption of 25 or $250 \mu \mathrm{g}$ of ginger extract/day had shown lower capacity to oxidize LDL-C and to take up and degrade oxidized LDL-C. Dietary consumption of ginger extract by $\mathrm{E}^{0}$ mice significantly attenuates the development of atherosclerotic lesions and reduces plasma LDL-C levels and their susceptibility to oxidation and aggregation. ${ }^{3}$

The modulatory effects of ginger on the metabolic syndrome and oxidative stress in STZ-nicotinamide diabetic rats have shown that the ginger may have a role in alleviating the risks of the metabolic syndrome and cardiovascular complications. ${ }^{40}$ Ethanol extract of ginger $(200 \mathrm{mg} / \mathrm{kg})$ reduces the serum and tissue cholesterol, serum triacylglycerol, serum lipoprotein, and phospholipid levels in cholesterol-fed rabbits, and the effect is comparable with gemfibrozil, a standard orally effective hypolipidemic drug. ${ }^{56}$ Oral administration of [6]-gingerol in type 2 diabetic $\mathrm{db} / \mathrm{db}$ mice decreases the plasma triglycerides, total cholesterol, free fatty acid, and LDL-C, suggesting that [6]-gingerol exhibits a significant potential as a lipid-lowering agent. ${ }^{57}$

The effects of air-dried ginger powder on experimentally induced atherosclerosis in rabbits showed reduction in the development of atheroma in aorta and coronary arteries by approximately $50 \%$, a decrease in lipid peroxidation, and an enhancement of fibrinolytic activity following ginger administration. However, it has been reported that ginger has no effect on blood lipids. This distinct antiatherogenic potential of ginger may be due to its free-radical-scavenging, prostaglandin-inhibitory, and fibrinolysis-enhancing properties. ${ }^{58}$ The protective effects of an ethanol extract of ginger at doses of 100, 200, and $400 \mathrm{mg} / \mathrm{kg}$ body weight on development of metabolic syndrome in a high-fat diet-fed rats showed significant reduction of body weight and a reduction in total cholesterol, LDL-C, triglycerides, free fatty acids, and phospholipids in serum of the rats, but no effect on serum high-density lipoprotein cholesterol. ${ }^{59}$ On the other hand, Bordia et $\mathrm{al}^{60}$ reported that ginger has no effect on the blood lipids and blood sugar. In contrast, another study has shown that the ethanol extract of ginger can protect the tissues from lipid peroxidation and exhibit lipid-lowering activity in diabetic rats. ${ }^{61}$

Administration of $80 \mathrm{mg} / \mathrm{kg}$ atorvastatin for 4 weeks showed a major hepatotoxic effect, whereas the lower dose $(20 \mathrm{mg} / \mathrm{kg}$ ) seems to cause mild liver injury. Besides lowering serum total cholesterol and hepatic SOD and catalase, atorvastatin significantly increased serum aminotransferases, hepatic malondialdehyde, and nitric oxide. Concurrent administration of ginger extract and atorvastatin had the opposite effect. A histopathological study revealed that ginger extract reduced liver lesions induced by atorvastatin. The results revealed that combination regimens containing ginger extract and low dose of statins could be advantageous in treating hypercholesterolemia patients who are susceptible to liver function abnormalities. ${ }^{62}$ In a double-blind controlled clinical trial with patients showed a reduction in triglyceride, cholesterol, LDL-C, and VLDL-C levels. ${ }^{63}$

\section{Blood pressure-lowering effect}

Ginger has been used traditionally in a wide variety of ailments, including hypertension. The crude extract of ginger induced a dose-dependent $(0.3-3 \mathrm{mg} / \mathrm{kg})$ fall in the arterial blood pressure of anesthetized rats and a cardiodepressant activity in guinea pigs. The blood-pressure-lowering effect of ginger is mediated through blockade of voltage-dependent calcium channels. ${ }^{5}$ In another study, it was reported that the aqueous ginger extract lowers blood pressure through a dual inhibitory effect mediated via stimulation of muscarinic receptors and blockade of $\mathrm{Ca}^{++}$channels, and this study provides sound mechanistic basis for the use of ginger in hypertension and palpitations. ${ }^{64}$ The effect of ginger tea on blood pressure of hypertensive individuals has been studied to determine and compare the mean arterial pressure, median number of hypertensive episodes of the respondents with and without intake of ginger tea. When the respondents started to drink $10 \mathrm{~g}$ of ginger tea twice a day from the 5 th to 8 th week, it has been shown that the average mean arterial pressure lowered to $94.804 \mathrm{mmHg} .{ }^{65}$

\section{Effect on platelet aggregation}

Based on recent studies, pungent constituents of ginger and its related substances represent a potential new class of antiplatelet agents. [6]-Gingerol, [6]-shogaol, [8]-gingerol, [8]-shogaol, [8]-paradol, and gingerol analogs exhibit antiplatelet activities. ${ }^{66,67}$ It has been reported that the halfmaximal inhibitory concentration $\left(\mathrm{IC}_{50}\right)$ values of ginger range from 3 to $7 \mu \mathrm{M}$, while aspirin showed an $\mathrm{IC}_{50}$ value of $20 \pm 11 \mu \mathrm{M} .{ }^{66}$ Most importantly, the COX-1 inhibitory activity of [8]-paradol is more potent than the gingerol analogs. The earlier findings reveal that gingerol compounds and their derivatives are more effective antiplatelet agents than aspirin under similar conditions and that [8]-paradol is found to be the most potent COX-1 inhibitor and antiplatelet aggregation agent of ginger. The mechanism underlying the arachidonic acid-induced platelet aggregation inhibition may be related to attenuation of COX-1/thromboxane synthase activity. ${ }^{66}$ In a similar study, gingerols and related analogs inhibited the 
arachidonic acid-induced platelet release reaction in a similar dose range as aspirin and also inhibited the human platelet aggregation. The mechanism underlying the inhibition of this platelet release reaction and aggregation by gingerol and its related analogs may be through regulation of COX activity in platelets, because gingerols potently inhibited COX activity in rat basophilic leukemia cells. ${ }^{68}$

Administration of powdered ginger at $4 \mathrm{~g} / \mathrm{d}$ for 3 months has no effect on platelet aggregation, fibrinolytic activity, and fibrinogen level in a placebo-controlled study with healthy individuals and patients with coronary artery disease and in diabetics. However, a single dose of $10 \mathrm{~g}$ powdered ginger administered to coronary artery disease patients produced a significant reduction in platelet aggregation induced by the two agonists. Similarly, it has been reported that the dosages of $5 \mathrm{~g}$ or more had antiplatelet activity. ${ }^{69}$ In a study with human subjects, it was reported that the ginger and nifedipine possessed synergistic effect on antiplatelet aggregation, and a combination of $1 \mathrm{~g}$ ginger with $10 \mathrm{mg}$ nifedipine per day could be valuable for cardiovascular and cerebrovascular complication due to platelet aggregation. ${ }^{4}$ However, more human trials are needed to find the effective minimum dosage of a standardized ginger extract.

\section{Chemoprevention and anticancer properties}

The cancer preventive properties of ginger are supposed to be mainly due to free radical scavenging, alteration of gene expressions, and induction of apoptosis, all of which contribute to inhibit or retard the tumor initiation, promotion, and progression. ${ }^{70}$ There are a number of mechanisms that contribute to the chemopreventive effects of ginger based on in vitro and in vivo studies. ${ }^{70}$ Purified ginger constituents such as [6]-, [8]-, and [10]-shogaols showed much stronger growth inhibitory effects than gingerols on H-1299 human lung cancer cells and HCT-116 human colon cancer cells. ${ }^{71}$ Some pungent constituents present in ginger, such as [6]-gingerol, [6]-paradol, shogaols, and zingerone, exhibit cancer preventive activity in experimental carcinogenesis. ${ }^{72}$ Ginger has been reported to possess chemopreventive activity in colon cancer. ${ }^{73}$ Gingerol also inhibits the growth of human colorectal cancer cells ${ }^{74}$ and induces apoptosis and autophagocytosis in ovarian cancer cells. ${ }^{75}$ Development of mammary tumors was significantly inhibited in mice with the supplement of hot water extract of ginger rhizome. ${ }^{76}$ Dietary phytochemicals offer nontoxic therapeutic management as well as chemopreventive intervention for slow-growing prostate cancers. Brahmbhatt et $\mathrm{al}^{77}$ recently reported growth-inhibiting and apoptosis-inducing properties of ginger extract in in vitro and in vivo prostate cancer models. These findings demonstrate that binary combinations of ginger phytochemicals synergistically inhibit proliferation of PC-3 cells with ChouTalalay combination-index values ranging from 0.03 to 0.88 . Furthermore, [6]-gingerol inhibits cell adhesion, invasion, motility, and activities of extracellular matrix-degrading enzymes (matrix metalloproteinases) of human breast cancer MDA-MB-231 cells. ${ }^{78}$ Therefore, [6]-gingerol may also contribute to the suppression of metastasis, and thus could also be explored for treating some cancer. The aforementioned mechanisms of ginger seem to be promising for cancer prevention and treatment; therefore, additional clinical studies are needed to assess the efficacy and safety of ginger.

\section{Other medicinal and toxicological properties}

Ginger is also an important commodity of many traditional medicines and has been extensively used in Chinese, Ayurvedic, Tibb-Unani, Sri Lankan, Arabic, and African traditional medicines to treat many unrelated human ailments including fever, sore throats, cold, vomiting, motion sickness, gastrointestinal diseases, indigestion, constipation, arthritis, rheumatism, sprains, muscular aches, pains, cramps, hypertension, dementia, fever, infectious diseases, and helminthiasis. Ginger has been traditionally used from time immemorial for varied human ailments in different parts of the world, to aid digestion and treat stomach upset, diarrhea, nausea, and migraine. Significantly fewer recorded incidences of nausea were reported in the group that received ginger root and was comparable with the placebo in a double-blind, randomized study with 60 women who had major gynecological surgery. ${ }^{79}$ Maghbooli et al ${ }^{80}$ undertook a comparative-effectiveness trial of ginger (250 $\mathrm{mg}$ of ginger rhizome powder) versus sumatriptan (50 mg, a synthetic drug used to treat migraine headache) in 100 adults with common migraine (no aura). Both medications demonstrated a $44 \%$ reduction in pain score 2 hours following the treatments, though it is unknown how much of this effect was due to natural history and/or a placebo response.

Systemic in vivo studies of the overall safety and toxicological effects of ginger are relatively rare. In a rat study, it has been reported that the administration of lower dosage of ginger $(50 \mathrm{mg} / \mathrm{kg} / \mathrm{d})$ showed no toxicity or histological changes in liver and lungs. ${ }^{81}$ When a patented ginger extract (EV.EXT33) was administered orally up to $1 \mathrm{~g} / \mathrm{kg}$ body weight to pregnant rats during the period of organogenesis, 
neither maternal nor developmental toxicity was observed. ${ }^{82}$ However, if ginger is consumed exceeding $6 \mathrm{~g} / \mathrm{d}$, then gastric irritation could occur in humans. ${ }^{1}$

\section{Conclusion}

Ginger is an important herb which exhibits many medicinal and ethnomedicinal properties. There are a number of bioactive compounds which are responsible for providing various medicinal properties of ginger. The major bioactive constituents in ginger are the gingerols, of which 6-gingerol is the most abundant. As reviewed in this study, recently conducted in vivo and in vitro studies revealed that ginger exhibits a significant potential due to its antibiotic, antioxidant, hypoglycemic, hypotensive, anti-inflammatory, lipid lowering, antiplatelet aggregation, and chemopreventive properties. However, most of these pharmacological effects of ginger need to be validated using proper clinical studies which could endorse the pharmacological value of ginger and its constituents.

\section{Disclosure}

The authors report no conflicts of interest in this work.

\section{References}

1. Chrubasika S, Pittlerc MH, Roufogalis BD. Zingiberis rhizoma: a comprehensive review on the ginger effect and efficacy profiles Phytomedicine. 2005; 12:684-701.

2. Ali BH, Blunden G, Tanira MO, Nemmar A. Some physico-chemical, pharmacological and toxicological properties of ginger (Zingerber officinale - a review. Food Chem Toxicol. 2008;46:409-410.

3. Fuhrman B, Rosenblat M, Hayek T, Coleman R, Aviram M. Ginger extract consumption reduces plasma cholesterol, inhibits LDL oxidation and attenuates development of atherosclerosis in atherosclerotic, apolipoprotein E-deficient mice. J Nutr. 2000;130(5): 1124-1131.

4. Young HY, Liao JC, Chang YS, Luo YL, Lu MC, Peng WH. Synergistic effect of ginger and nifedipine on human platelet aggregation: a study in hypertensive patients and normal volunteers. Am J Chin Med. 2006;34(4):545-551.

5. Ghayur MN, Gilani AH, Janssen JL. Ginger attenuates acetylcholineinduced contraction and $\mathrm{Ca}^{+2}$ signaling in murine airway smooth muscle cells. Can J Physiol Pharmacol. 2008;86:264-271.

6. Butt MS, Sultan MT. Ginger and its health claims: molecular aspects. Crit Rev Food Sci Nutr. 2011;51(5):383-393.

7. Suekawa M, Ishige A, Yuasa K, Sudo K, Aburada M, Hosoya E. Pharmacological studies on ginger. I. Pharmacological actions of pungent constituents, (6)-gingerol and (6)-shogaol. J Pharmacobiodyn. 1984;7:836-848.

8. Gunathilake KDPP, Pitts N, Rupasinghe HPV. Formulation and characterization of a bioactives-enriched fruit beverage designed for cardio-protection. Food Res Int. 2013;52(2):535-541.

9. Gunathilake KDPP, Wang Y, Rupasinghe HPV. Hypocholesterolemic and hypotensive effects of a fruit-based functional beverage in spontaneously hypertensive rats fed with cholesterol-rich diet. J Funct Foods. 2013;5(3):1392-1401.

10. Wang X, Zheng Z, Guo X, Yuan J, Zheng C. Preparative separation of gingerols from Zingiber officinale by high-speed counter-current chromatography using stepwise elution. Food Chem. 2011;125: 1476-1480.
11. Jolad SD, Lantz RC, Solyon AM, Chen GJ, Bates RB, Timmermann BN. Fresh organically grown ginger (Zingiber officinale): composition and effects on LPS-induced PGE2 production. Phytochemistry. 2004;65: 1937-1954.

12. Masuda Y, Kikuzaki H, Hisamoto M, Nakatani N. Antioxidant properties of gingerol related compounds from ginger. Biofactors. 2004;21(1-4):293-296.

13. Ekwenye UN, Elegalam NN. Antibacterial activity of ginger (Zingiber officinale Roscoe) and garlic (Allium sativum L) extracts on Escherichia coli and Salmonella typhi.J Mol Med Adv Sci. 2005;1(4): 411-416.

14. Malu SP, Obochi GO, Tawo EN, Nyong BE. Antibacterial activity and medicinal properties of ginger (Zingiber officinale). Glob J Pure Appl Sci. 2008;15(3):365-368.

15. Park M, Bae J, Lee D-S. Antibacterial activity of [10]-gingerol and [12]-gingerol isolated from ginger rhizome against periodontal bacteria. Phytother Res. 2008;22(11):1446-1449.

16. Wang HM, Chen CY, Chen HA, et al. Zingiber officinale (ginger) compounds have tetracycline-resistance modifying effects against clinical extensively drug-resistant Acinetobacter baumannii. Phytother Res. 2010;24(12):1825-1830.

17. Sebiomo A, Awofodu AD, Awosanya AO, Awotona FE, Ajayi AJ. Comparative studies of antibacterial effect of some antibiotics and ginger (Zingiber officinale) on two pathogenic bacteria. J Microbiol Antimicrob. 2011;3(1):18-22.

18. Akoachere JFTK, Ndip RN, Chenwi EB, Ndip LM, Njock TE, Anong DN. Antibacterial effects of Zingiber officinale and Garcinia kola on respiratory tract pathogens. East Afr Med J. 2002;79(11):588-592.

19. Betoni JEC, Mantovani RP, Barbosa LN, Stasi LCD, Fernandes Junior A. Synergism between plant extract and antimicrobial drugs used on Staphylococcus aureus diseases. Mem Inst Oswaldo Cruz. 2006;101(4):387-390.

20. Mahady GB, Pendland SL, Yun GS, Lu Z, Stoia A. Ginger (Zingiber officinale Roscoe) and the gingerols inhibit the growth of Cag A+ strains of Helicobacter pylori. Anticancer Res. 2003;23:3699-3702.

21. Maizura M, Aminah A, Aida WMW. Total phenolic content and antioxidant activity of kesum (Polygonum minus), ginger (Zingiber officinale) and turmeric (Curcuma longa) extract. Int Food Res J. 2011;18(2):529-534.

22. Ghasemzadeh A, Jaafar HZE, Rahmat A. Effects of solvent type on phenolics and flavonoids content and antioxidant activities in two varieties of young ginger (Zingiber officinale Roscoe) extracts. $J$ Med Plant Res. 2011;5(7):1147-1154.

23. Shirin APR, Prakesh JJ. Chemical composition and antioxidant properties of ginger root (Zingiber officinale). $J$ Med Plants Res. 2010;4:2674-2680.

24. Kim JK, Kim Y, Na KM, Surh YJ, Kim TY. [6]-Gingerol prevents UVB-induced ROS production and COX-2 expression in vitro and in vivo. Free Radic Res. 2007;41(5):603-614.

25. Gunathilake KDPP, Rupasinghe HPV. Inhibition of human low density lipoprotein oxidation in vitro by ginger extracts. J Med Food. 2014;17(4):424-431.

26. Afshari AT, Alireza S, Amirabbas F, et al. The effect of ginger on diabetic nephropathy, plasma antioxidant capacity and lipid peroxidation in rats. Food Chem. 2007;101(1):148-153.

27. Aeschbach R, Löliger J, Scott BC, et al. Antioxidant actions of thymol, carvacrol, 6-gingerol, zingerone and hydroxytyrosol. Food Chem Toxicol. 1994;32:31-36.

28. Madamanchi NR, Vendrov A, Runge MS. Oxidative stress and vascular disease. Arterioscler Thromb Vasc Biol. 2005;25:29-38

29. Katsube T, Tabata H, Ohta Y, et al. Screening for antioxidant activity in edible plant products; comparison of LDL oxidation assay, DPPH assay and FC assay. J Agric Food Chem. 2004;52:2391-2396.

30. Gunathilake KDPP, Rupasinghe HPV. Optimization of water basedextraction methods for the preparation of bioactive rich ginger extract using response surface methodology. Eur J Med Plants. 2014;4(8):893-906. 
31. Ahmed RS, Vandana S, Banerjee BD. Influence of dietary ginger (Zingiber officinale Rosc) on antioxidant defense system in rat: comparison with ascorbic acid. Indian J Exp Biol. 2000;38(6):604-606.

32. Stoilova I, Krastanov A, Stoyanova A, Denev P, Gargova S. Antioxidant activity of a ginger extract (Zingiber officinale). Food Chem. 2007; 102(3):764-770.

33. Ghasemzadeh A, Jaafar HZE, Rahmat A. Antioxidant activities, total phenolics and flavonoids content in two varieties of Malaysia young ginger (Zingiber officinale Roscoe). Molecules. 2010;15(6): 4324-4333.

34. Parmar I, Rupasinghe HPV. Antioxidant capacity and anti-diabetic activity of wild berry stem infusions. Eur J Med Plants. 2015;8:11-28.

35. Abdulrazaq NB, Cho MM, Win NN, Zaman R, Rahman MT. Beneficial effects of ginger (Zingiber officinale) on carbohydrate metabolism in streptozotocin-induced diabetic rats. Br J Nutr. 2012;108(7): 1194-1201.

36. Jafri SA, Abass S, Qasim M. Hypoglycemic effect of ginger (Zingiber officinale) in alloxan induced diabetic rats (Rattus norvagicus). PakVet $J$. 2010;31(2):160-162.

37. Sukalingama K, Ganesana K, Ganib SB. Hypoglycemic effect of 6-gingerol, an active principle of ginger in streptozotocin induced diabetic rats. Res Rev J Pharmacol Toxicol Stud. 2013;96:660-666.

38. Sattar NA, Hussain F, Iqbal T, Sheikh MA. Determination of in vitro antidiabetic effects of Zingiber officinale Roscoe. Braz J Pharm Sci. 2012;48(4):601-607.

39. Noipha K, Ratanachaiyavong S, Ninla-Aesong P. Enhancement of glucose transport by selected plant foods in muscle cell line L6. Diabetes Res Clin Pract. 2010;89(2):e22-e26.

40. Madkor HR, Mansour SW, Ramadan G. Modulatory effects of garlic, ginger, turmeric and their mixture on hyperglycaemia, dyslipidaemia and oxidative stress in streptozotocin-nicotinamide diabetic rats. $\mathrm{Br} \mathrm{J}$ Nutr. 2011;105(8):1210-1217.

41. Saraswat M, Suryanarayana P, Reddy PY, Patil MA, Balakrishna N, Reddy GB. Antiglycating potential of Zingiber officinalis and delay of diabetic cataract in rats. Mol Vis. 2010;16:1525-1537.

42. Rani MP, Krishna MS, Padmakumari KP, Raghu KG, Sundaresan A. Zingiber officinale extract exhibits antidiabetic potential via modulating glucose uptake, protein glycation and inhibiting adipocyte differentiation: an in vitro study. $J$ Sci Food Agric. 2012;92(9):1948-1955.

43. Mahluji S,Attari VE, Mobasseri M, Payahoo L, Ostadrahimi A, Golzari SE. Effects of ginger (Zingiber officinale) on plasma glucose level, $\mathrm{HbA}_{1 c}$ and insulin sensitivity in type 2 diabetic patients. Int J Food Sci Nutr. 2013;64(6):682-686.

44. Andallu B, Radhika B, Suryakantham V. Effect of aswagandha, ginger and mulberry on hyperglycemia and hyperlipidemia. Plant Foods Hum Nutr. 2003;58(3):1-7.

45. Rani PM, Padmakumari KP, Sankarikutty B, Lijo Cherian O, Nisha VM, Raghu KG. Inhibitory potential of ginger extracts against enzymes linked to type 2 diabetes, inflammation and induced oxidative stress. Int J Food Sci Nutr. 2011;62(2):106-110.

46. Srivastava KC, Mustafa T. Ginger (Zingiber officinale) in rheumatism and musculoskeletal disorders. Med Hypotheses. 1992;39(4):342-348.

47. Grzanna R, Lindmark L, Frondoza CG. Ginger - an herbal medicinal product with broad anti-inflammatory actions. $J$ Med Food. 2005;8(2):125-132.

48. Singletary K. Ginger: an overview of health benefits. Nutr Today. 2010;45:171-183.

49. Ojewole JA. Analgesic, antiinflammatory and hypoglycaemic effects of ethanol extract of Zingiber officinale (Roscoe) rhizomes (Zingiberaceae) in mice and rats. Phytother Res. 2006;20(9):764-772.

50. Dugasani S, Pichika MR, Nadarajah VD, Balijepalli MK, Tandra S, Korlakunta JN. Comparative antioxidant and anti-inflammatory effects of [6]-gingerol,[8]-gingerol,[10]-gingerol and [6]-shogaol. J Ethnopharmacol. 2010;127(2):515-520.

51. Habib SHM, Makpol S, Hamid NAA, Das S, Ngah WZW, YusofYAM. Ginger extract (Zingiber officinale) has anti-cancer and anti-inflammatory effects on ethionine-induced hepatoma rats. Clinics (Sao Paulo). 2008;63(6):807-813.
52. Minghetti P, Sosa S, Cilurzo F, et al. Evaluation of the topical antiinflammatory activity of ginger dry extracts from solutions and plasters. Planta Med. 2007;73(15):1525-1530.

53. Ramadan G, Al-Kahtani MA, El-Sayed WM. Anti-inflammatory and anti-oxidant properties of Curcuma longa (Turmeric) versus Zingiber officinale (Ginger) rhizomes in rat adjuvant-induced arthritis. Inflammation. 2011;34(4):291-301.

54. Young HY, Luo YL, Cheng HY, Hsieh WC, Liao JC, Peng WH. Analgesic and anti-inflammatory activities of [6]-gingerol. $J$ Ethnopharmacol. 2005;96(1):207-210

55. Thomson M, Al-Qattan KK, Al-Sawan SM, Alnaqeeb MA, Khan I, Ali M. The use of ginger (Zingiber officinale Rosc) as a potential antiinflammatory and antithrombotic agent. Prostaglandins Leukot Essent Fatty Acids. 2002;67(6):475-478.

56. Bhandari U, Sharma JN, Zafar R. The protective action of ethanolic ginger (Zingiber officinale) extract in cholesterol fed rabbits. J Ethnopharmacol. 1998;61(2):167-171.

57. Singh AB, Akanksha SN, Maurya R, Srivastava AK. Anti-hyperglycaemic, lipid lowering and anti-oxidant properties of [6]-gingerol in $\mathrm{db} / \mathrm{db}$ mice. Int J Med Med Sci. 2009;1(12):536-544.

58. Verma SK, Singh M, Jain P, Bordia A. Protective effect of ginger, Zingiber officinale Rosc on experimental atherosclerosis in rabbits. Indian J Exp Biol. 2004;42(7):736-738.

59. Nammi S, Sreemantula S, Roufogalis BD. Protective effects of ethanolic extract of Zingiber officinale rhizome on the development of metabolic syndrome in high-fat diet-fed rats. Basic Clin Pharmacol Toxicol. 2009;104(5):366-373.

60. Bordia A, Verma SK, Srivastava KC. Effect of ginger (Zingiber officinale Rosc) and fenugreek (Trigonella foenumgraecum L) on blood lipids, blood sugar and platelet aggregation in patients with coronary artery disease. Prostaglandins Leukot Essent Fatty Acids. 1997;56(5):379-384.

61. Bhandari U, Kanojia R, Pillai KK. Effect of ethanolic extract of Zingiber officinale on dyslipidaemia in diabetic rats. $J$ Ethnopharmacol. 2005;97(2):227-230.

62. Heeba GH, Abd-Elghany MI. Effect of combined administration of ginger (Zingiber officinale) and atorvastatin on the liver of rats. Phytomedicine. 2010;17(14):1076-1081.

63. Alizadeh-Navaei R, Fatemeh R, Mehrdad S, Mehdi P, Farzad J, Moghadamnia AA. Investigation of the effect of ginger on the lipid levels. A double blind controlled clinical trial. Saudi Med J. 2008;29(9):1280-1284.

64. Ghayur MN, Anwarul HG, Afridi MB, Houghton PJ. Cardiovascular effects of ginger aqueous extract and its phenolic constituents are mediated through multiple pathways. Vascul Pharmacol. 2005;43(4): 234-241.

65. Aming SN. The effect of twice a day intake of ginger tea on the blood pressure of hypertensive individuals in Barnagay La Victoria, Aurora, Zambonga Del Sur. Herdin Record \#: R09-ZCHRD-12043023205433. 2006 (abstract).

66. Nurtjahja-Tjendraputra E, Ammit AJ, Roufogalis BD, Tran VH, Duke CC. Effective anti-platelet and COX-1 enzyme inhibitors from pungent constituents of ginger. Thromb Res. 2003;111(4):259-265.

67. Liao Y-R, Leu Y-L, Chan Y-Y, Kuo P-C, Wu T-S. Anti-platelet aggregation and vasorelaxing effects of the constituents of the rhizomes of Zingiber officinale. Molecules. 2012;17:8928-8937.

68. Koo KLK, Ammit AJ, Tran VH, Duke CC, Roufogalis BC. Gingerols and related analogues inhibit arachidonic acid-induced human platelet serotonin release and aggregation. Thromb Res. 2001;103(5):387-397.

69. Nicoll R, Henein MY. Ginger (Zingiber officinale Roscoe): a hot remedy for cardiovascular disease? Int J Cardiol. 2009;131(3):408-409.

70. Baliga MS, Haniadka R, Pereira MM, et al. Update on the chemopreventive effects of ginger and its phytochemicals. Crit Rev Food Sci Nutr. 2011;51(6):499-523.

71. Sang S, Hong J, Wu H, et al. Increased growth inhibitory effects on human cancer cells and anti-inflammatory potency of shogaols from Zingiber officinale relative to gingerols. J Agric Food Chem. 2009;57(22):10645-10650. 
72. Shukla Y, Singh M. Cancer preventive properties of ginger: a brief review. Food Chem Toxicol. 2007;45(5):683-690.

73. Akhani SP, Vishwakarma SL, Goyal RK. Anti-diabetic activity of Zingiber officinale in streptozotocin-induced type I diabetic rats. J Pharm Pharmacol. 2004;56(1):101-105.

74. Bode A, Dong ZG. Ginger is an effective inhibitor of HCT116 human colorectal carcinoma in vivo. Cancer Epidemiol Biomarkers Prev. 2003;12(11):1324S.

75. Rhode JM, Huang J, Fogoros S, Tan L, Zick S, Liu JR. Ginger induces apoptosis and autophagocytosis in ovarian cancer cells. Cancer Res. 2006;66(8 Suppl):1058.

76. Nagasawa H, Watanabe K, Inatomi H. Effects of bitter melon (Momordica charantia 1) or ginger rhizome (Zingiber officinale Rosc) on spontaneous mammary tumorigenesis in SHN mice. Am JChin Med. 2002;30(2-3):195-205.

77. Brahmbhatt M, Gundala SR, Asif G, Shamsi SA, Aneja R. Ginger phytochemicals exhibit synergy to inhibit prostate cancer cell proliferation. Nutr Cancer. 2013;65:263-272.
78. Lee HS, Seo EY, Kang NE, Kim WK. [6]-Gingerol inhibits metastasis of MDA-MB-231 human breast cancer cells. $J$ Nutr Biochem. 2008;19(5):313-319.

79. Bone ME, Wilkinson DJ, Young JR, McNeil J, Charlton S. Ginger root - a new antiemetic. The effect of ginger root on postoperative nausea and vomiting after major gynaecological surgery. Anaesthesia. 1990;45(8):669-671.

80. Maghbooli M, Golipour F, Esfandabadi AM, Yousefi M. Comparison between the efficacy of ginger and sumatriptan in the ablative treatment of the common migraine. Phytother Res. 2014;28(3):412-415.

81. Al-Naqeeb MA, Thomson M, Al-Qattan K, Kamel F, Mustafa T, Ali M. Biochemical and histopathological toxicity of an aqueous extract of ginger in female rats. Kuwait J Sci Eng. 2003;30(2):35-48.

82. Weidner MS, Sigwart K. The safety of a ginger extract in the rat. J Ethnopharmacol. 2000;73:513-520.

Botanics: Targets and Therapy

\section{Publish your work in this journal}

Botanics: Targets and Therapy is an international, peer-reviewed, open access journal focusing on the discovery and development of active compounds based upon or found naturally occurring in the plant kingdom that may have therapeutic potential in any disease state. The manuscript management system is completely online and includes a very

quick and fair peer-review system. Visit http://www.dovepress.com/ testimonials.php to read real quotes from published authors. 